\title{
Ecological Responses of Lakes to Climate Change
}

\author{
Karl Havens ${ }^{1, *}$ and Erik Jeppesen ${ }^{2,3}$ \\ 1 Florida Sea Grant College Program, University of Florida IFAS, Building 803 McCarty Drive, Gainesville, \\ FL 32611, USA \\ 2 Department of Bioscience, Aarhus University, Vejlsøvej 25, 8600 Silkeborg, Denmark; ej@bios.au.dk \\ 3 Sino-Danish Centre for Education and Research, University of Chinese Academy of Sciences, \\ Beijing 100190, China \\ * Correspondence: khavens@ufl.edu
}

Received: 14 May 2018; Accepted: 9 July 2018; Published: 11 July 2018

\section{Introduction}

Lakes around the world are being affected by climate change, and that includes changes in their physics, chemistry and biology, as well as interactions between their internal compartments and with their surrounding watersheds [1-3]. The ecological responses of lakes to climate change will become more pronounced in the future, with continued global warming, increased evapotranspiration, altered patterns of rain and drought, and disrupted or amplified climate teleconnections [4,5]. The continued ability of lakes to provide habitat to thousands of aquatic species and ecosystem services to society is threatened as lakes diminish in size, become more saline, and/or have highly altered thermal properties. At least one of the factors that is occurring with climate change-warming of lake water-is known to have synergistic effects with nutrient enrichment, by stimulating blooms of toxic cyanobacteria in eutrophic lakes [6,7] and by altering food-web structure [5]. Likewise, complex interactions occur when other physical or chemical properties are altered. Changes in salinity affect composition and diversity of the various biota and alter trophic structure and dynamics [8]. Changes in thermal stratification or duration of ice cover affect fishes and, in turn, alter the top-down control of plankton. This can have cascading effects on the food web [1]. Other synergistic and/or complex effects likely exist and are yet to be documented as we continue to learn more about the responses of different kinds of lakes to a warming earth.

Impacts of climate change on lakes are important because lakes play a critical role in the landscape, providing nesting habitat for birds and foraging habitat and a source of water for many terrestrial animals, and they play a substantive role as sources and sinks of carbon $(\mathrm{C})$ and nitrogen $(\mathrm{N})$ gases, as well as oxygen $(\mathrm{O})$. For the human population, lakes are a major source of drinking water, irrigation water, recreation and fisheries resources, and they can have major cultural and economic significance. Knowing all of this, it is remarkable that in many nations, funds are being directed away from the careful assessment of changes in lakes in response to climate change. This is happening at a time when quantification of the rates of change is most needed to help understand processes and possible tipping points and to identify measures to increase resilience.

The aim of this special issue is to call attention to contemporary research that has been done to document how lakes around the world are changing in response to climate change and to provide insight into the growing body of knowledge about expected future changes. The summary below provides the highlights of 11 original research papers contained in the issue, in the context of prior work, and it identifies implications for lake management, for the services that lakes provide to society, and points to research gaps where further work is needed. 


\section{Contributions}

\subsection{Lake Warming}

Lakes around the world are warming at a rapid rate, as documented recently in a survey of 235 lakes $[9,10]$ showing an increase in the mean surface temperature by $0.34{ }^{\circ} \mathrm{C}$ per decade between 1985 and 2009. Less is known about the warming that has occurred in water deeper under the lake surface, where a larger percentage of organisms occur. In this special issue, Richardson et al. [11] quantified changes in water column temperatures and thermal stratification in 231 lakes in North America over the period 1975 to 2012. The dataset included lakes varying in their mixing regime, size, trophic state, and geomorphology.

On average, the lakes displayed an increase in water temperature near the surface, as also observed by O'Reilly et al. [9] in a global lakes assessment, and most lakes displayed an increase in the strength of thermal stratification. On average, surface waters warmed 1.7 times faster than corresponding air temperatures at the lakes. Lakes with high water transparency (Secchi disk depth $>5 \mathrm{~m}$ ) had greater warming of surface waters and greater increases in stratification than lakes with lower transparency. Polymictic lakes displayed the greatest increase in warming throughout their water columns. The mean change in deep water temperature, the major new focus of this study, was not significantly different from zero. Approximately half of the lakes warmed and half cooled during the period of record. Likewise, a study of 20 Danish lakes revealed a warming in the surface water of ca. $2{ }^{\circ} \mathrm{C}$ per year and a simultaneous cooling of deep water by ca. $1{ }^{\circ} \mathrm{C}$ over the period 1989 to 2006 [12].

Certain characteristics were linked to how lakes in North America changed over time. Distance of the lakes to the coastline was the most important explanatory variable; that is, coastal lakes cooled and inland lakes warmed in their deeper waters. Elevation, shading by vegetation, duration of ice cover, input of ground water, and other factors may have contributed to the trend in deep water temperature changes observed. Two particularly important findings of this study were: (1) that lakes are an important sentinel of global warming due to their more rapid temperature increase than the overlying atmosphere; and (2) that there is considerable variability in lake response to climate change, implying that intensive studies of just prominent lakes will not suffice to understand how lakes in general will change in future decades.

In addition to long-term synoptic assessment, an approach that is likely to become important to projecting the future of lake thermal properties in a warming world, is coupled modeling. In this special issue, Kwak et al. [13] used a model that can simulate hydrological and thermal responses of water bodies to warming, and coupled it with output from the Coupled Model Inter-Comparison Project Phase 5 (CMIP5) Global Circulation Models (GCMs). They evaluated the projected effects of three future climate scenarios on the Fourchue River, Quebec, Canada.

The hydrologic model predicted that under these three scenarios, of global warming by 1.0, 1.8, and $3.7^{\circ} \mathrm{C}$ by 2100 , the river will experience an increase in water temperature between 0.2 and $0.7^{\circ} \mathrm{C}$ in June and between 0.2 and $1.1^{\circ} \mathrm{C}$ in September. It is noteworthy that the Fourchue River is a coastal ecosystem and, as such, warming by a lesser amount than occurs in the atmosphere is consistent with the findings of the first paper in this issue by Richardson et al. [11]. The model predictions have ecological and management implications for the river system. This river is a critical habitat for brook trout (Salvelinus fontinalis) and the predicted increases in temperature could be favorable to growth. However, the model results also indicated that there will be several days in the summer when temperatures exceed the upper incipient lethal temperature for this species and that might require releases of cold water from the reservoir into the river to prevent fish mortality.

To evaluate how altered thermal properties of lakes might affect the structure and function of their food webs, studies have compared lakes at different latitudes, studied lakes for a long period of time as they have warmed, and in this special issue Arvola et al. [14] present the results from an experiment where the mixing regime was artificially altered over a 4-year period. Two small lakes (4.7 and 4.1 ha) 
in Finland were selected for the study. They were both soft-water lakes of approximately $6 \mathrm{~m}$ depth, with high dissolved organic carbon (DOC) and phytoplankton Chlorophyll- $a$ (Chl- $a$ ) of approximately $15 \mu \mathrm{g} \mathrm{L}^{-1}$. In the experiment, one lake was a control, while the other was mixed by placing an electrically-driven propeller at $1.5 \mathrm{~m}$ depth under a raft anchored at the deepest location, pumping water from the metalimnion into the epilimnion. This artificial mixing occurred from May to September 2005 and again from June to September 2006. The plankton, macro-invertebrates, and fish of both lakes were sampled weekly from 2004 to 2006 and biweekly in 2007, a year after the mixing ended. Neither total phytoplankton biomass nor Chl- $a$ concentrations changed as a result of the artificial mixing. However, the manipulated lake developed an increase in the relative biomass of diatoms and cryptophytes. Crustacean zooplankton biomass did not change in the mixed lake compared with the control; however, biodiversity increased following mixing, but only in the metalimnion. Rotifer density declined in the mixed lake relative to the control, but only in the hypolimnion where protozoan density increased. Certain taxa of littoral macroinvertebrates increased after the mixing, while others declined in density. One food web response, an increase in the growth of perch (Perca fluviatilis) in the mixed lake, was attributed to improved food availability. Another response, the appearance of ruffe (Gymnocephalus cernuus) in 2006, was attributed to enhanced oxygenation of the benthic habitat used by this animal. The authors concluded that the response of perch is 'one of the best indications that water column manipulation influenced the entire food web and the responses were cascading to the upper trophic levels'. Another food web effect that was discovered in this experiment was a decline in the mercury $(\mathrm{Hg})$ concentration in perch. This was explained as being caused by a mixing-induced reduction of mercury methylation by sulfate-reducing bacteria and an increased contribution of methane-derived carbon in the food web from enhanced activity of methane-oxidizing bacteria. In summary, the experiment demonstrated that climate-change induced alterations in the mixing regime of small humic lakes can have effects on the structure and function of the entire food web, including processes that influence concentrations of toxic metals at higher trophic levels.

Warming has the potential to greatly alter the rates of $C$ emissions from natural landscapes. Wetlands, including those that surround lakes, can be major sources of sinks for $\mathrm{C}$, depending on the conditions [15]. Camacho et al. [16] note that emission of methane $\left(\mathrm{CH}_{4}\right)$, one of the most potent greenhouse gases, is enhanced by warming and, as such, climate change could spark a feedback loop where warming enhances $\mathrm{CH}_{4}$ emission and emission contributes to more warming. Those authors quantified $\mathrm{CH}_{4}$ emissions from five saline lakes in central Spain. The lakes varied in their hydroperiod, salinity, and trophic state. They conducted controlled experiments with intact sediment cores from the lakes, varying the temperature and salinity, and then used a model to extrapolate the results under different climate scenarios for 2050 and 2070. In general, and as expected, the rates of $\mathrm{CH}_{4}$ emission from sediment cores were lower in times when sediments were dry and when temperatures were lower. In the experiments, $\mathrm{CH}_{4}$ emission increased in a non-linear manner with warming, especially between 25 and $30^{\circ} \mathrm{C}$, and it decreased in a non-linear manner with increasing salinity, dropping quickly from the maximal value at a conductivity of below $5 \mathrm{mS} \mathrm{cm}^{-1}$ to $20 \mathrm{mS} \mathrm{cm}^{-1}$ and then leveling off between 60 and $150 \mathrm{mS} \mathrm{cm}^{-1}$. In general, the lakes were predicted to have large increases in $\mathrm{CH}_{4}$ emission in 2050 and 2070; however, the outcome depends on sediment flooding vs. drying, with a projection of the highest rates of $\mathrm{CH}_{4}$ emission coming from lakes where the sediments remain flooded throughout a dry season. To understand the effects that climate change might have on lakes, we therefore also must consider future changes in hydrology.

\subsection{Changes in Hydrology and Land Use}

In addition to warming the atmosphere and hydrosphere, global warming is expected to alter climate cycles, including those that connect oceanic thermal cycles such as the El Niño Southern Oscillation (ENSO) to multi-year cycles in weather at distant locations around the world [17]. These teleconnections have major influences on the physics, chemistry and biology of world-wide lakes [18-20], and there is increasing evidence that the amplitude of ENSO and other cycles will 
increase with atmospheric warming [21]. The result of this could be intensified droughts and concentration of rain into intense shorter-lasting periods of time. Changes like this could have profound effects on the transfer of nutrients and organic material from the landscape into lakes and would accentuate cycles of flood and drought that occur in many areas of the world. Intense droughts might lead to salinization of lakes, concentration of nutrients, and synergistic effects with atmospheric warming on water temperature increase.

Global warming is also expected to result in intensification of tropical cyclones [4], which can have major impacts on shallow lowland lakes in the subtropics [22]. An approach to gain insights into how such changes might affect lakes is to study the responses to contemporary events that are outside the range of typical conditions. For example, Zhu et al. [23] examined the response of Lake Taihu in China to repeated hurricane strikes and discussed how storms of greater intensity or frequency of occurrence could lead to a loss of ecosystem resilience from these catastrophic events, and Ji et al. [24] documented long-lasting changes in species composition of plankton in Lake Okeechobee (USA) after an unusual case of three major hurricanes impacting the lake in two successive years.

In this special issue, Ji et al. [25] examine how a regular cycle of high and low water levels, linked to the condition of the ENSO, affects water quality and zooplankton in shallow lakes of central Florida, USA. Water depth, chemistry, phytoplankton, and zooplankton were examined from a 15-year dataset with monthly samples from 6 shallow (mean depth 1.4 to $3.4 \mathrm{~m}$ ) eutrophic (Chl- $a 35$ to $65 \mu \mathrm{g} \mathrm{L}^{-1}$ annual mean) polymictic lakes. All of the lakes contained high densities of the benthivorous gizzard shad (Dorosoma cededianum), a filter-feeding fish that consumes plankton and also feeds on macro-invertebrates in the sediments, and that can translocate a considerable amount of soluble P into the water column [26]. In the study period, there was cyclic variation in rainfall linked to the ENSO, with three droughts and four wet periods. Rainfall was significantly correlated with lake depth, with the lakes losing as much as $80 \%$ of their volume in periods of lowest compared with highest depth. The result was a concentration of fish and zooplankton in a small volume of water during droughts and also a large increase in the biomass of filamentous cyanobacteria, presumably because of greater nutrient availability. During droughts, cladocerans consistently declined, while copepods were not affected, and the authors concluded that variation in water depth, driven by the climate cycle, affected both the top-down and the bottom-up factors that control the zooplankton. Cladocerans were more greatly affected than copepods because: (1) cladocerans are more susceptible to fish predation [27]; and (2) cladocerans are less able to tolerate high densities of inedible cyanobacteria-results documented in earlier studies [28,29]. If, as predicted [21], the amplitude of the ENSO increases over the next 50 years with further global warming, effects of the associated teleconnection on lakes may also increase, and in the case of shallow eutrophic lakes this could result in synergistic adverse effects with nutrient pollution—greater internal loading, more toxic cyanobacteria, and an altered assemblage of zooplankton.

As noted earlier, lakes themselves can be a substantive contributor to atmospheric C, particularly if they have large associated wetlands. In addition to warming, hydrologic changes associated with climate change might affect those $\mathrm{C}$ fluxes. Yang et al. [30] quantified emissions of $\mathrm{CO}_{2}$ from the littoral zone of a reservoir in Beijing, China, taking measurements with a dark chamber and gas chromatography techniques along a transect from a permanently flooded location to a seasonally flooded location and then to dry land. They also compared emissions from places with different vegetation types within each hydrographic band. Sampling was done at six different times of the year to account for seasonal variability. The authors found in general that the littoral wetland was a much greater source of $\mathrm{CO}_{2}$ (averaging $346 \mathrm{mg} \mathrm{m}^{-2} \mathrm{~h}^{-1}$ ) than the pelagic, based on an average of data from ten nearby Chinese lakes (pelagic mean, $72 \mathrm{mg} \mathrm{m}^{-2} \mathrm{~h}^{-1}$ ). A majority of published studies of the $\mathrm{CO}_{2}$ flux from lakes have focused on the pelagic zone, and the results indicate a need for more measurements of the littoral $C$ flux, especially in lakes with a large littoral to pelagic surface ratio. With regard to experimental results, there was considerable variation related to location, time of year, time of day, and biomass of plants in the plots along the hydrologic gradient. The effect of flooding on 
$\mathrm{CO}_{2}$ emission was complex; however, it was noted that in the periodically flooded band, if flooding resulted in plant growth, this shifted the $C$ balance and the uptake by plants exceeded the loss of $C$ to the atmosphere, even when taking into account loss from $\mathrm{CH}_{4}$. The regime of flooding vs. water recession in vegetated shorelines, and the time of year when it happens relative to the growing season, could have a large influence on the degree to which lakes are sources vs. sinks of $C$.

As climate continues to change, and sea levels rise, there will likely be mass migration of human populations away from impacted coastal areas as well as movement in the location where certain kinds of natural and farmed vegetation exist. An interaction could therefore occur between changes in land use, warming and the changes in climate cycles just mentioned. For example, if land use changes to one that exports a higher amount of nutrients into a lake, the synergistic effects of warming and increased nutrient concentrations could lead to greater prevalence and toxicity of cyanobacteria blooms in eutrophic lakes as described above. Likewise, if a change in land use transforms a wetland/forest area into urban, agricultural, or residential use, it will be accompanied by a faster movement of water, $\mathrm{C}$, and other materials from the watershed to a lake-compared with slow movement through natural systems. If climate change leads to prolonged droughts interspersed with intense rain events, such a modified watershed would have very different effects on a lake compared to a non-disturbed one. However, these are major lasting changes, and there may be some alternations in land use that are of shorter duration and that do not have these synergistic effects with climate change. In this special issue, Levesque et al. [31] consider one such example-clear-cut logging in boreal Canada. They examine the long-term (1991-2003) temporal variation in zooplankton in six lakes to determine how they are affected by variation in precipitation, limnological conditions, and by factors linked to logging. Prior studies have documented that clear-cut logging can have significant effects on boreal lakes by altering nutrient and DOC inputs, transparency, primary productivity, and food web structure [32-34]. However, most of the watershed disturbances in those studies were short-term, lasting not more than three years, and the effects on zooplankton were relatively small.

The aim of the study performed by Levesque et al. [31] was to test whether natural variation in climate and limnological conditions are more important than the short-term impacts of logging. To do this, the authors performed whole-lake experiments. They collected zooplankton from the water column of three experimental lakes during a 5-year period before clear-cut logging and during an 8-year period after logging. Sampling was twice per month in the ice-free season. Three other lakes in non-disturbed watersheds were sampled in exactly the same manner and were controls. There was considerable variation in temperature and precipitation (rain and snow) amongst the years of study, and this influenced the zooplankton in both experimental and control lakes. In all of the lakes, there was also temporal variation in the concentrations of major ions, $\mathrm{pH}$, dissolved organic carbon, total phosphorus, total nitrogen, and Chl- $a$. Zooplankton experienced a substantive decline in total abundance over the study period in both the experimental and the control lakes. There were some subtle interactions between climate variations and logging; however, for the most part, the study revealed that variability in climate and limnological conditions (depth, residence time) had a stronger influence on the zooplankton than did logging. The authors note projections of warming in the boreal shield by $8{ }^{\circ} \mathrm{C}$ in winter and conclude that this will result in reduced abundance of zooplankton, in particular calanoid copepods.

While we intuitively expect that, for many other kinds of land use change, particular modifications that are long-lasting will influence how climate affects lakes, there are no experimental studies like that done by Levesque et al. [31] to confirm this, because it is not feasible. The gap could be filled with long-term assessment of lakes with similar limnological characteristics and climate variation but different land uses, or by scenario modeling. This is a critical research need.

\subsection{Related Topics}

It is critical that researchers and lake managers be able to track changes in lakes that are occurring over time and that might be related to climate variability and change. Yet, with diminishing funding 
for long-term assessment, this is becoming increasingly difficult and the importance of low-cost yet effective sampling approaches is high. Submerged aquatic plants (SAV) are often a sentinel for the broader ecological status of lake ecosystems, especially shallow lakes [35] and they are highly responsive to some of the changes in lakes expected to occur with climate change such as altered drought severity [4]. Traditional field sampling of SAV is labor-intensive and costly. In this special issue, Fritz et al. [36] explore the efficacy of a remote sensing method-studying changes in the SAV community in Lake Starnberg, Germany, in the growing seasons of 2011 to 2015 based on ground-truthed reflectance spectra. They develop 'phenologic fingerprints' for each SAV species and characterize changes in the plant assemblage with some degree of error that needs to be addressed with further research. Their study also documented that changes in water temperature had a lesser effect on an invasive species than two native species. This is yet another issue of climate change-effects on the relative abundance and biomass of species within particular assemblages in the lake.

One of the prominent effects of global warming is the world-wide melting and retreat of glaciers [4]. The ecological and societal implications of this phenomenon are tremendous, because while meltwater may for a period of time be high, once those glaciers are gone, it will disrupt the supply of freshwater into some of the world's major rivers that provide water supply, industrial water, irrigation water, fisheries, and a route for commerce in places with tens of millions of people. At the present time, melting of glaciers is known to be responsible for transporting organic $C$ to downstream ecosystems [37], and that $C$ subsequently fuels food webs that are based on bacteria-plankton. One of the regions experiencing rapid glacial change due to warming is the Tibetan Plateau. In this special issue, $\mathrm{Hu}$ et al. [38] examine the extent to which organic $\mathrm{C}$ from glacial runoff subsidizes the plankton food web in Lake Nam Co, a typical high altitude lake in the Plateau. They did this by focusing on the zooplankton and using stable $\mathrm{C}$ isotope analysis and radio-carbon to determine the basal source of $\mathrm{C}$ in their diets. They concluded that $74 \%$ of the $\mathrm{C}$ in zooplankton diets is from phytoplankton, $18 \%$ is from a microbial food web fueled by decomposing SAV, and just a small fraction (8\%) can be attributed to allochthonous glacial meltwater C. However, they also note that with enhanced inputs of water and organic $C$ from glacial runoff, there is a potential to stimulate plankton production in the lakes of the Tibetan Plateau.

As previously mentioned, if climate change displaces populations and this results in changes in land-use around lakes, there could be an indirect effect on those aquatic ecosystems, if the changes result in increased inputs of nutrients, $\mathrm{C}$, or sediments, or a change in the rate at which rainfall over the watershed makes its way into the lake. Therefore, it is important to understand how the attributes of lake ecosystems are affected by land use patterns. Xu et al. [39] studied 14 lakes located in the Yangtze River Basin and quantified recent rates of sediment deposition, and then evaluated their results in the context of a variety of features of the lakes and their watersheds. Their finding is that conversion of land to agriculture for growing crops or to urban uses can lead to substantial increases in the sedimentation rate. High rates of sediment accumulation can lead to reduced depth and ecosystem services of water bodies, impacts on benthic biota, and degraded water quality. The study reinforces why it is critical to consider climate change and land use change in tandem when considering future changes in lakes.

One general question that has been raised amongst limnologists is whether or not climate change will have different effects on lakes at different latitudes. When considering the zooplankton, a major focus is on predation, because it often is the major factor determining body size, total biomass, and taxonomic composition [40], especially in shallow lakes [27]. Changes in the zooplankton can, in turn, affect the phytoplankton, clarity, and thus indirectly even the submerged vegetation. Iglesias et al. [41] carried out controlled experiments using $1000 \mathrm{~L}$ in situ enclosures in shallow lakes in Uruguay and Denmark, in order to compare the effects of presence vs. absence of small omnivorous and planktivorous fish and/or invertebrate predators on the zooplankton and phytoplankton. The enclosures contained common artificial plant beds, so that it was possible also to examine effects on periphyton accumulation. Each treatment (fish, invertebrates, fish+invertebrates, control) was 
replicated in four enclosures at both study sites. They found that in both climatic zones the addition of fish resulted in a decline in zooplankton and an increase in the biomass of phytoplankton. In both zones, macro-invertebrates did not have significant effects. Neither fish nor macro-invertebrates affected the biomass of periphyton. The results of this study support the view that in shallow lakes, omnivorous and planktivorous fish may play a critical role in pushing the lakes into a turbid, phytoplankton-dominated state by facilitating development of phytoplankton when their zooplankton predators are severely depleted. While this study did not show clear differences in responses between the climate zones, another study in which fish and invertebrates could move freely between the open water and the plant beds indicated strong fish-induced differences, resulting in high predation on zooplankton and macro-invertebrates [42]. The two studies, conducted in the same two countries, collectively identify the overarching role that change in habitat selection may have in shallow lakes when the climate gets warmer.

\section{Conclusions}

Climate change is documented to have major implications for the structure, function, and ecosystem services provided by lakes. With increasing global warming, climate changes will affect lakes by warming, by altering the thermal stratification, and by altering the hydrology, and there are likely to be interactive effects of climate change and substantive changes in land use if people migrate away from flooded coastal cities into the proximity of lakes. Lakes might display direct effects, such as increased algal blooms where warming has synergistic effects with high nutrient inputs, and indirect effects, where changes in fish assemblages have cascading effects that influence plankton, water clarity, and submerged vegetation. With warming, especially in the littoral zones of lakes, there may be large-scale changes in the net flux of $\mathrm{CO}_{2}$ and $\mathrm{CH}_{4}$ to and from the atmosphere, contributing to a feedback loop where warming causes greater $\mathrm{C}$ flux from the natural systems to the atmosphere, which leads to further warming. Despite a breadth of research, some key uncertainties remain about how climate change will affect lakes, and it will require continued research and long-term assessment to fully understand and predict future changes and effects on society.

Author Contributions: K.H. wrote the first draft, and E.J. contributed to the final version.

Funding: Erik Jeppesen was supported on this project by a sabbatical grant from Aarhus University and by AU Centre for Water Technology (WATEC.AU.DK).

Acknowledgments: The authors are grateful to four anonymous reviewers for comments on an earlier version of this manuscript.

Conflicts of Interest: The authors declare no conflict of interest.

\section{References}

1. Jackson, L.J.; Lauridsen, T.L.; Søndergaard, M.; Jeppesen, E. A comparison of shallow Danish and Canadian lakes and implications for climate change. Freshw. Biol. 2007, 52, 1782-1792. [CrossRef]

2. Kosten, S.; Huszar, V.L.M.; Becares, E.; Costs, L.S.; van Donk, E.; Hansson, L.A.; Jeppesen, E.; Kruk, C.; Lacerot, G.; Mazzeo, N.; et al. Warmer climates boost cyanobacterial dominance in shallow lakes. Glob. Chang. Biol. 2012, 18, 118-126. [CrossRef]

3. Shurin, J.B.; Clasen, J.L.; Greig, H.S.; Kratina, P.; Thompson, P.L. Warming shifts top-down and bottom-up control of pond food web structure and function. Philos. Trans. R. Soc. 2012, 367, 3008-3017. [CrossRef] [PubMed]

4. Intergovernmental Panel on Climate Change (IPCC). Contribution of working group I to the fifth assessment report of the Intergovernmental Panel on Climate Change. In Climate Change 2013: The Physical Science Basis; Stocker, T.F., Qin, D., Plattner, G.K., Tignor, M., Allen, S.K., Boschung, J., Nauels, A., Xia, Y., Bex, B., Midgley, B., Eds.; Cambridge University Press: Cambridge, UK, 2013. 
5. Jeppesen, E.; Meerhoff, M.; Davidson, T.A.; Trolle, D.; Søndergaard, M.; Lauridsen, T.L.; Beklioglu, M.; Brucet, S.; Volta, P.; Gonzalez-Bergonzoni, I.; et al. Climate change impacts on lakes: An integrated ecological perspective based on a multi-faceted approach, with special focus on shallow lakes. J. Limnol. 2014, 73, 88-111. [CrossRef]

6. Paerl, H.W.; Huisman, J. Blooms like it hot. Science 2008, 320, 57-58. [CrossRef] [PubMed]

7. Havens, K.E.; Paerl, H.W. Climate change at a crossroad for control of harmful algal blooms. Environ. Sci. Technol. 2015, 49, 12605-12606. [CrossRef] [PubMed]

8. Jeppesen, E.; Brucet, S.; Naselli-Flores, L.; Papastergiadou, E.; Stefanidis, K.; Nõges, T.; Nõges, P.; Attayde, J.L.; Zohary, T.; Coppens, J.; et al. Ecological impacts of global warming and water abstraction on lakes and reservoirs due to changes in water level and salinity. Hydrobiologia 2015, 750, 201-227. [CrossRef]

9. O'Reilly, C.M.; Sharma, S.; Gray, D.K.; Hampton, S.E.; Read, J.S.; Rowley, J.R.; Schneider, P.; Lenter, J.D.; McIntyre, P.B.; Kraemer, B.M.; et al. Rapid and highly variable warming of lake surface waters around the globe. Geophys. Res. Lett. 2015. [CrossRef]

10. Sharma, S.; Gray, D.K.; Read, J.S.; O’Reilly, C.M.; Schneider, P.; Qudrat, A.; Gries, C.; Stefanoff, S.; Hampton, S.E.; Hook, S.; et al. A global database of lake surface temperatures collected by in situ and satellite methods from 1985 to 2009. Sci. Data 2015. [CrossRef] [PubMed]

11. Richardson, D.C.; Melles, S.J.; Pilla, R.M.; Hetherington, A.L.; Knoll, L.B.; Williamson, C.E.; Kraemer, B.M.; Jackson, J.R.; Long, E.C.; Moore, K.; et al. Transparency, geomorphology and mixing regime explain variability in trends in lake temperature and stratification across northeastern North America (1975-2014). Water 2017, 9, 442. [CrossRef]

12. Jeppesen, E.; Søndergaard, M.; Lauridsen, T.L.; Liboriussen, L.; Bjerring, R.; Johanssen, L.S.; Landkildehus, F.; Kronvang, B.; Andersen, H.E.; Trolle, D.; et al. Recent climate induced changes in freshwaters in Denmark. In Climatic Change and Global Warming of Inland Waters: Impacts and Mitigation for Ecosystems and Societies; Goldman, C.R., Kumagari, M., Robarts, R.D., Eds.; John Wiley \& Sons: Hoboken, NJ, USA, 2012; pp. $156-171$.

13. Kwak, J.; St-Hilaire, A.; Chebana, F.; Kim, G. Summer season water temperature modeling under the climate change: Case study for Fourchue River, Quebec, Canada. Water 2017, 9, 346. [CrossRef]

14. Arvola, L.; Rask, M.; Forsius, M.; Ala-Opas, P.; Keskitalo, J.; Kulo, K.; Kurkilahti, M.; Lehtovaara, A.; Sairanen, S.; Salo, S.; et al. Food web responses to artificial mixing in a small boreal lake. Water 2017, 9, 515. [CrossRef]

15. Kayranli, B.; Scholz, M.; Mustafa, A.; Hedmark, Å. Carbon storage and fluxes within freshwater wetlands: A critical review. Wetlands 2010, 30, 111-124. [CrossRef]

16. Camacho, A.; Picazo, A.; Rochera, C.; Santamans, A.C.; Morant, D.; Miralles-Lorenzo, J.; Castillo-Escriva, A. Methand emissions in Spanish saline lakes: Current rates, temperature and salinity responses, and evolution under different climate change scenarios. Water 2017, 9, 659. [CrossRef]

17. Abtew, W.; Trimble, P. El niño-southern oscillation link to south Florida hydrology and water management applications. Water Resour. Manag. 2010, 24, 4255-4271. [CrossRef]

18. Cózar, A.; Bruno, M.; Bergamino, N.; Ubeda, B.; Bracchini, L.; Dattilo, A.M.; Loiselle, S.A. Basin-scale control on the phytoplankton biomass in Lake Victoria, Africa. PLoS ONE 2012, 7, e29962. [CrossRef] [PubMed]

19. Darchambeau, F.; Borges, A.V.; Sarmento, H.; Leporcq, B.; Isumbisho, P.M.; Alunga, G.; Masilya, P.M.; Descy, J.-P. Teleconnections between Ecosystem Productivity and Climate Indices in a Tropical Great Lake. In EGU General Assembly Conference Abstracts; EGU: Vienna, Austria, 2013; Volume 15.

20. Van Cleave, K.; Lenters, J.D.; Wang, J.; Verhamme, E.M. A regime shift in Lake Superior ice cover, evaporation, and water temperature following the warm El Niño winter of 1997-1998. Limnol. Oceanogr. 2014, 59, 1889-1898. [CrossRef]

21. Cai, W.; Santoso, A.; Wang, G.; Yeh, S.-W.; An, S.-I.; Cobb, K.M.; Collins, M.; Guilyardi, E.; Jin, F.-F.; Kug, J.-S.; et al. ENSO and greenhouse warming. Nat. Clim. Chang. 2015, 5, 849-859. [CrossRef]

22. Havens, K.E.; Fulton, R.S.; Beaver, J.R.; Samples, E.E.; Colee, J. Effects of climate variability on cladoceran zooplankton and cyanobacteria in a shallow subtropical lake. J. Plankton Res. 2016, 38, 418-430. [CrossRef]

23. Zhu, M.; Paerl, H.W.; Zhu, G.; Wu, T.; Li, W.; Shi, K.; Zhao, L.; Zhang, Y.; Qin, B.; Caruso, A.M. The role of tropical cyclones in stimulating Cyanobacteria (Microcystis spp.) blooms in hypertrophic Lake Taihu, China. Harmful Algae 2014, 39, 310-321. [CrossRef]

24. Ji, G.; Havens, K.E.; Beaver, J.R.; East, T.L. Recovery of plankton from hurricane impacts in a large shallow lake. Freshw. Biol. 2018, 63, 366-379. [CrossRef] 
25. Ji, G.; Havens, K.E.; Beaver, J.R.; Fulton, R.S., III. Response of zooplankton to climate variability: Droughts create a perfect storm for cladocerans in shallow eutrophic lakes. Water 2017, 9, 764. [CrossRef]

26. Schaus, M.H.; Vanni, M.J.; Wissing, T.E.; Bremigan, M.T.; Garvey, J.E.; Stein, R.A. Nitrogen and phosphorus excretion by detritivorous gizzard shad in a reservoir ecosystem. Limnol. Oceanogr. 1997, 42, 1386-1397. [CrossRef]

27. Jeppesen, E.; Meerhoff, M.; Jacobsen, B.A.; Hansen, R.S.; Sondergaard, M.; Jensen, J.P.; Lauridsen, T.L.; Mazzeo, N.; Branco, C.W.C. Restoration of shallow lakes by nutrient control and biomanipulation-The successful strategy varies with lake size and climate. Hydrobiologia 2007, 581, 269-285. [CrossRef]

28. Hansson, L.-A.; Gustafsson, S.; Rengefors, K.; Bomark, L. Cyanobacterial chemical warfare affects zooplankton community composition. Freshw. Biol. 2007, 52, 1290-1301. [CrossRef]

29. Fabre, A.; Lacerot, G.; de Paiva, R.R.; Soares, M.C.S.; de Magalhães, V.F.; Bonilla, S. South American PSP toxin-producing Cylindrospermopsis raciborskii (Cyanobacteria) decreases clearance rates of cladocerans more than copepods. Hydrobiologia 2017, 785, 61-69. [CrossRef]

30. Yang, M.; Grace, J.; Geng, X.; Guan, L.; Zhang, Y.; Lei, J.; Lu, C.; Lei, G. Carbon dioxide emissions from the littoral zone of a Chinese reservoir. Water 2017, 9, 539. [CrossRef]

31. Lévesque, D.; Pinel-Alloul, B.; Méthot, G.; Steedman, R. Effects of climate, limnological features and watershed clearcut logging on long-term variation in zooplankton communities of Boreal Shield lakes. Water 2017, 9, 733. [CrossRef]

32. Rask, M.; Nyberg, K.; Markkanen, S.-L.; Ojala, A. Forestry in catchments: Effects on water quality, plankton, zooplankton and fish in small lakes. Boreal Environ. Res. 1998, 3, 75-86.

33. Carignan, R.; D'Arcy, P.; Lamontagne, S. Comparative impacts of fire and forest harvesting on water quality in Boreal Shield lakes. Can. J. Fish. Aquat. Sci. 2000, 57, 105-117. [CrossRef]

34. Winkler, G.; Leclerc, V.; Sirois, P.; Archambault, P.; Berube, P. Short-term impact of forest harvesting on water quality and zooplankton communities in oligotrophic headwater lakes of the eastern Canadian Boreal Shield. Boreal Environ. Res. 2009, 14, 323-337.

35. Moss, B.; Madgwick, J.; Phillips, G. A Guide to the Restoration of Nutrient-Enriched Shallow Lakes; The Broads Authority: Norwich, UK, 1997; 180p.

36. Fritz, C.; Schneider, T.; Geist, J. Seasonal variation in spectral response of submerged aquatic macrophytes: A case study at Lake Starnberg (Germany). Water 2017, 9, 527. [CrossRef]

37. Hood, E.; Battin, T.J.; Fellman, J.; Neel, S.O.; Spencer, R.G. Storage and release of organic carbon from glaciers and ice sheets. Nat. Geosci. 2015, 8, 91-96. [CrossRef]

38. Hu, E.; He, H.; Su, Y.; Jeppesen, E.; Liu, Z. Use of multi-carbon sources by zooplankton in an oligotrophic lake in the Tibetan Plateau. Water 2017, 8, 565. [CrossRef]

39. Xu, M.; Dong, X.; Yang, X.; Chen, X.; Zhang, Q.; Liu, Q.; Wang, R.; Yao, M.; Davidson, T.A.; Jeppesen, E. Recent sedimentation rates of shallow lakes in the middle and lower reaches of the Yangtze River: Patterns, controlling factors and implications for lake management. Water 2017, 9, 617. [CrossRef]

40. Carpenter, S.R. Regime Shifts in Lake Ecosystems: Pattern and Variation; International Ecology Institute: Oldendorf, Germany, 2003; 199p.

41. Iglesias, C.; Jeppesen, E.; Mazzeo, N.; Pacheco Pablo, J.; Teixeira-de Mello, F.; Landkildehus, F.; Fosalba, C.; Clemente, J.M.; Meerhoff, M. Fish but not macroinvertebrates promote trophic cascading effects in high density submersed plant experimental lake food webs in two contrasting climate regions. Water 2017, 9, 514. [CrossRef]

42. Meerhoff, M.; Clemente, J.M.; Teixeira de Mello, F.; Iglesias, C.; Pedersen, A.R.; Jeppesen, E. Can warm climate-related structure of littoral predator assemblies weaken the clear water state in shallow lakes? Glob. Chang. Biol. 2007, 13, 1888-1897. [CrossRef]

(C) 2018 by the authors. Licensee MDPI, Basel, Switzerland. This article is an open access article distributed under the terms and conditions of the Creative Commons Attribution (CC BY) license (http://creativecommons.org/licenses/by/4.0/). 